\title{
Iron, brain and neuropsychiatric problem
}

\author{
Viroj Wiwanitkit
}

Received: 16 January 2012/ Accepted: 25 February 2012/Published online: 16 March 2012

(C) Springer Science+Business Media, LLC. 2012

Sir, the publication on "Transition metal abnormalities in progressive" is very interesting (Akatsu et al. 2011). In this work, several biometal levels in brain in several neuropsychiatric conditions such as Alzheimer's disease, bipolar and depression were investigated. Akatsu et al. (2011) observed that "Iron was found to be increased by $38 \%$ in $\mathrm{AD}$ amygdala tissues." Indeed, the abnormality of iron metabolism is proved to be the risk of ageing white matter lesions and can be the leading cause of several neurophychiatric problems (Gebril et al. 2011). From a previous study on suicidal depression victims, a clear correlation between iron level and strand breaks in the brain regions could be observed (Mustak et al. 2010). Hence, the assessment of the iron metabolism in the cases with neuropsychiatric problem might be useful. Due to the possibility of co-morbidity between iron overload and neuropsychiatric disorder, the iron study should be done in all cases presenting with depressive disorder (Koch et al. 2012). According to a recent case report, the management of iron overload by phlebotomy can result in dramatic improvement of neuropsychiatric symptoms (Koch et al. 2012).

\section{References}

Akatsu H, Hori A, Yamamoto T, Yoshida M, Mimuro M, Hashizume Y, Tooyama I, Yezdimer EM (2011) Transition metal abnormalities in progressive dementias. Biometals. doi:10.1007/s10534-011-9504-8

Gebril OH, Simpson JE, Kirby J, Brayne C, Ince PG (2011) Brain iron dysregulation and the risk of ageing white matter lesions. Neuromolecular Med 13:289-299

Koch HJ, Husan P, Nanev D, Zellmer H, Hönicke H (2012) Two cases of hemochromatosis associated with severe depressive episodes. Case Study Case Rep 2:4-7

Mustak MS, Hegde ML, Dinesh A, Britton GB, Berrocal R, Subba Rao K, Shamasundar NM, Rao KS, Sathyanarayana Rao TS (2010) Evidence of altered DNA integrity in the brain regions of suicidal victims of bipolar depression. Indian J Psychiatry 52:220-228
V. Wiwanitkit $(\bowtie)$

Wiwanitkit House, Bangkhae, Bangkok, Thailand

e-mail: wviroj@yahoo.com 